'I hereby present the use of the Latin first-person perfect indicative as a performative'

\author{
Höfler, Stefan
}

Published in:

Lemmata Linguistica Latina

Publication date:

2019

Document version

Peer reviewed version

Citation for published version (APA):

Höfler, S. (2019). 'I hereby present the use of the Latin first-person perfect indicative as a performative'. In L. van Gils, C. Kroon, \& R. Risselada (Eds.), Lemmata Linguistica Latina: Volume II: Clause and Discourse (pp. 374-390). De Gruyter. 


\title{
Stefan Höfler
}

\section{'I hereby present the use of the Latin first-person perfect indicative as a performative'}

\begin{abstract}
The aim of this chapter is to show that the Latin first-person perfect indicative was used as a performative speech act. Evidence for this claim will be gathered from texts in which the first-person uses instantaneous speech or instantaneous writing (letters, legal contracts, graffiti, curse tablets, etc.). It will be shown that the usage of speech or writing act verbs (e.g. scrīpsī, dēuouĩ) is different from the epistolary use of past tense forms for present actions. In the end, however, the question must be left open whether this usage is a syntactic Grecism or inherited from Proto-Indo-European.
\end{abstract}

Keywords: Latin linguistics, performative, speech act, tragic aorist, epistolary tense

\section{Starting point}

In 1959, a banker's archive was excavated just outside ancient Pompeii that consists of over 100 wax tablets of largely legistic content, connected to moneylending activities recorded over the years 26-62 CE. The collection is now known as the Tabulae Pompeianae Sulpiciorum. A typical text found in these tablets, a chirograph (or holograph; see below Section 4), can be seen in (1).

(1) C(aio) Cessasare Germanico Aug(usto)

Tì(berio) Claudio Germanico co(n)s(ulibus),

VI nonas İulias. C(aius) Nouius Eunus

scripssi me accepisse muta ab

\begin{abstract}
Acknowledgment: I hereby express my gratitude to Jay Jasanoff (Harvard) and Martin Peters (Vienna) for inspiring discussions on this topic, to several participants of the colloquium for their invaluable comments, as well as to two anonymous reviewers and the editors for their important suggestions and apt critique from which this paper has benefited immensely. Of course, however, no endorsement of any specific ideas or conclusions is implied.
\end{abstract}

Stefan Höfler, Harvard University

https://doi.org/10.1515/9783110678222-020 
5 Hessco Eunni Tì(berii) Cessaris Augusti

l(iberti) Primiani ser(vo) [[muta]] et

debere ei sestertia tra milia

nummu, pret(er) alia HS $\bar{X}$ n(ummum)

que alio chirographo meo

10 eidem debo, et ea sestertia

tra milia num(mum) \{nummu\},

$q($ uae) s(upra) s(cripta) s(unt), $p($ roba $)\{r($ ecte $)\}$ recete dari

stipulatus ets Hessucus Euni

Tì(berii) Cessaris Augustì l(iberti) Primiani

ser(vus) spepodi ego C(aius) Novius Eunus,

in qua ominis suma dedì eì

5 pignoris tridigi Alxadrini modi=

um septe mila, quot est possit[um]

in horeis Bassianis puplicis Putola[nor(um)]

medis horeo duode[cimo], et sacos ducen[t]=

os lentis c[ice]r[is .. ]+issi monocopi

10 et faris in quibus sunt modium

quator milia, qui sunt possiti in

isdem horeis, que ominia ab omini

vi priculo meo est, fator.

Actum Putolis. (TPSulp. 52 pp. 2 and 3)

'Under the consuls Gaius Caesar Germanicus Augustus and Tiberius Claudius Germanicus on the sixth day before the Nones of July [= July 2, 37 CE]: I, Gaius Novius Eunus, confirm that I received as loans from and owe to Hesychus, the slave of Evenus Primianus, the freedman of Tiberius Caesar Augustus, 3.000 sesterces in coins, in addition to the other 10.000 sesterces in coins, which by another chirograph of mine I owe to him.

Hesychus, the slave of Evenus Primianus, the freedman of Tiberius Caesar Augustus, stipulated that the 3.000 sesterces, described above, be given back to him correctly and in good coin. I, Gaius Novius Eunus, solemnly promise to do so.

For the whole sum, I gave him as a pledge 7.000 modii of Alexandrian wheat, which is stored in the Bassian Public Granaries of the Puteolans, on middle level in granary 12, and 200 sacks of lentils, chickpeas, 
monocopi, and flour, which hold 4.000 modii, which are placed in the same granaries, and for which as a whole I take responsibility against all danger, as I herewith declare. Done at Puteoli., ${ }^{1}$

What is immediately striking about this text is the use of the first-person perfect indicative scrīpsī (in line 2.4; written scripssi) instead of the present scrībō (and likewise spepodi in line 3.3 instead of spondeō), a use that is perhaps not easily understood at first glance. For the meaning of the phrase clearly is 'I, Gaius Nouius Eunus, confirm that I received ...' and not 'I, Gaius Nouius Eunus, ${ }^{\star}$ confirmed/^have written down that I had/have received ... '. Logic basically requires that the first-person perfect scrīpsī 'I wrote' always implies a writing process in the past and that it never refers to the present act of writing, which, however, seems to be the case here (cf. also the use of the first-person present fat $[e]$ or 'I declare' in line 3.13).

The goal of this contribution will, therefore, be to find out why the authors of this type of contracts did use the perfect scrīpsī here, to find other comparable first-person perfect indicative forms in a similar usage, and eventually to try to explain the origin of this custom.

\section{The Latin perfect}

According to the handbooks (Weiss 2009: 452-456 [cf. also the discussion in note 17 on p. 452]; Pinkster 2015: 442-455; cf. also Haverling 2002), the Latin perfect descriptively functions as a ('present') perfect and a ('narrative') past tense, as seen in examples (2) and (3) respectively.

(2) modo intellexi quam rem mulier gesserit. (PlavT. Mil. 867)

'I've just realized [= and now understand] what the girl has been doing.'

(3) ueni, uidi, uici. (SVET. Iul. 37, 2)

'I came, I saw, I conquered.'

1 The Latin text is from the critical edition Camodeca (1999: 139). The chirograph was discussed in depth by Rowe (2005) (cf. also Sirks 2016: 267; Obcarskas 2017: 17-18); for the man behind the name C. Novius Eunus cf. Tchernia (2016: 266-269); for the monetary background of the Sulpician treaties cf. Verboven (2017); on the interpretation of lines 3.12-13 as a possible syntactic Grecism cf. Calboli (2009: 145-146). 
These two functions reflect the origin of the Latin perfect which formally continues two separate categories of Proto-Indo-European (PIE): the (resultative) perfect (e.g. pepercī) and the (perfective) aorist (e.g. parsī). ${ }^{2}$ While the latter re-

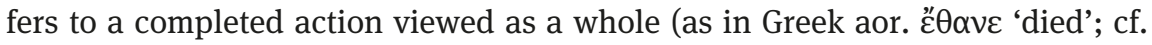
semantically uēnī 'I came' in example (3)), the former (formally marked by reduplication) was used to describe a past event with present relevance, or a present state resulting from, or obtained by, a past action (as in Greek perf.

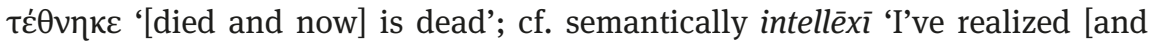
now understand]' in example (2)).

Some scholars have also identified a specific usage of the perfect that is found in letters and is called 'Perfekt des Briefstils' or 'epistolary perfect' (cf. e.g. Kühner and Stegmann 1912: 156-159; Bringmann 1971: 93, n. 20): the writer uses the perfect for a present action (mostly mittere and scribere) because he or she knows that by the time the reader receives the letter, the action is already accomplished, ${ }^{3}$ as in (4).

(4) (beginning of the letter) Nonis Quintilibus ueni in Puteolanum. postridie iens ad Brutum in Nesidem haec scripsi. (CIC. Att. 16, 1, 1)

'I arrived at Puteoli on the 7th. I write / wrote this on the following day as I am / was crossing to Nesis to meet Brutus.'

In this case, scrīpsi - exceptionally! - refers to the present act of writing, as opposed to what has been said in Section 1. It is evident that the epistolary use of the perfect here is an adoption of the perspective of the reader. The fact, however, that one of the most prominent examples of the 'Perfekt des Briefstils' is scrīpsī can at least partly be otherwise explained, as will be shown in Section 6.

2 Of no importance for the present study is the small number of verbs that (seem to) continue the resultative meaning of the perfect and do not have contrasting present stems in (classical) Latin ( $\bar{d} \overline{\mathrm{l}}$ 'I hate', meminī 'I remember', nōuī 'I know').

3 Cf. also the definition of 'epistolary tense' by Danckaert (2017: 155): “Epistolary tenses are a (rather marked) device by means of which the sender of a letter adopts the temporal perspective of the reader, in order to bridge the interval between his/her own hic et nunc and the moment when the message reaches the addressee (often at least a couple of days later). So despite the fact that epistolary tenses always take the shape of a preterital verb, they can be considered a sort of 'über-present', as they are meant to simultaneously refer to the present of the sender and the present of the addressee.” He only cites examples of epistolary imperfects, however. This is confirmed by Pinkster (2015: 413), who only mentions the use of imperfect forms in epistolary use. 


\section{The Greek tragic aorist and the 'Koinzidenzfall'}

In Greek, the aorist is generally used as a simple 'narrative' past tense with perfective aspect as in (5).

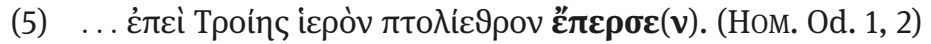

'. . . after he (had) sacked the sacred citadel of Troy.'

Among other special usages, the first-person aorist indicative can be used as a performative speech act. This phenomenon, the so-called 'tragic aorist' (also 'dramatic aorist') (cf. Lloyd 1999; Bary 2012) is used when the verb expresses an action performed by the very act of speaking, as in example (6).

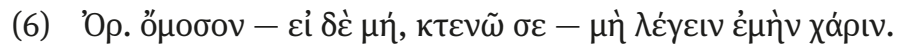

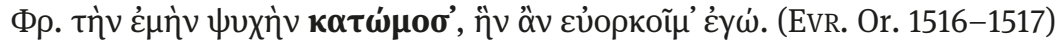

'Or.: Swear you are not saying this to humor me, or I will kill you.

Phr.: I (hereby) swear by my life, an oath I would keep!'

In this case, the uttering of $\kappa \alpha \tau \omega \dot{\mu o \sigma \alpha}$ 'I hereby swear' constitutes the oath itself. What is important to note is that, of course, no 'real' past tense reading ( ‘'I swore by my life') is possible here.

The tragic aorist is confined to the first-person and appears only with a restricted class of verbs (mostly verba dicendi). In English, a translation using the words 'hereby', 'herewith' (German 'hiermit') is not only the most suitable rendition of the tragic aorist, but also serves as a cross check for whether or not a first-person aorist indicative can be regarded a true tragic aorist. Since Koschmieder (1965: 26), this special case of performative speech act has been known as the 'Koinzidenzfall':

Ich war bei der Untersuchung der Funktion der sog. 'Tempora' im Hebräischen durch den Fall bērachti ' $\bar{o} p \bar{o}=$,ich segne ihn hiermit' darauf aufmerksam geworden, daß es sich hierbei um einen Sonderfall handelt, in dem nämlich das Aussprechen des Satzes nicht nur von der Handlung spricht, sondern auch eben die betr. Handlung ist; die bezeichnete Handlung findet nicht nur gleichzeitig mit dem Aussprechen des betr. Satzes statt, wie in den übrigen Fällen der typischen Gegenwart, z. B. ich schreibe eben, ich lese gerade, jetzt lasse ich los, usw., sondern sie besteht überaupt [sic] im Aussprechen des Satzes. (Koschmieder 1965: 26-27; bold print mine, SH)

Examples from modern-day languages for instances of a 'Koinzidenzfall' are, among others, formulaic expressions such as I (hereby) name this ship 'Queen Elizabeth', I hereby invite you to attend a meeting of the Finance Committee, I solemnly swear that I'm up to no good, or German Hiermit erkläre ich Sie zu 
Mann und Frau, Ich bitte dich hiermit um Verzeihung. Note that in all of these sentences, the action is constituted by the utterance of the phrase itself.

Within Greek, there is also the possibility to use the first-person present indicative for the 'Koinzidenzfall', as shown by example (7).

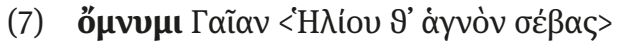

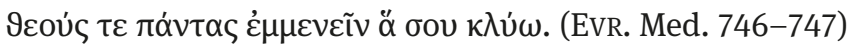

'I swear by Earth, by the holy worship of Helios, and by all the gods that I will do as I hear from you.' (Bary 2012: 35)

Bary 2012 (with references to previous accounts) offers a very attractive explanation for this phenomenon. According to her, the Greek 'tense-aspect pair' system can be illustrated as in Table 1 (Bary 2012: 37; similarly Willi 2018: 13). Note that Table 1 is simplified and ignores future tense and 'resultative' aspect (expressed by the Greek perfect and pluperfect).

Table 1: The Greek ‘tense-aspect pair’ system (simplified).

\begin{tabular}{|c|c|c|}
\hline & present tense & past tense \\
\hline imperfective aspect & 'present' & 'imperfect' \\
\hline perfective $^{a}$ aspect & $-{ }^{\mathrm{b}}$ & 'aorist' \\
\hline \multicolumn{3}{|c|}{$\begin{array}{l}\text { a Bary (2012: } 37 \text { ) uses the term 'aoristic aspect' for what is usually } \\
\text { known as 'perfective aspect'. } \\
\text { b Willi (2018: 13) mentions the 'gnomic aorist' as a possible exception } \\
\text { to the illicit combination of present tense and perfective aspect, } \\
\text { which seems rather suspect. }\end{array}$} \\
\hline
\end{tabular}

It is widely accepted that the Greek situation faithfully reflects the distribution of tense and aspect in (late) PIE, where perfective aspect (i.e. the verbal action being viewed as a complete whole) was expressed by the aorist stem (confined to the 'aorist' in past tense), while imperfective aspect (i.e. the event being presented as ongoing, continuous, or habitual) was conveyed by the present stem (used as the 'present' and the 'imperfect' for present and past tense respectively). ${ }^{4}$ Thus, already in PIE times there was a gap in the system: there was no morphological possibility to express the combination of perfective aspect and present tense.

4 Cf. Weiss (2009: 378-379). 
Bary, however, concludes that it is exactly this combination that would constitute the ideal form for performative utterances such as 'I (hereby) swear', 'I (hereby) apologize'. This is not only evident "since event time and moment of utterance coincide" (Bary 2012: 50) but also corroborated by the fact that the verbal action is performed and completed by the utterance of the sentence, which in theory demands perfective aspect. As in PIE, however, the combination of perfective aspect and present tense does not exist in Greek.

"In the absence of the optimal form, two suboptimal forms are equally good: the form for present tense and imperfective aspect and the form for past tense and aoristic [see Table 1, note a, $\mathrm{SH}$ ] aspect. The latter is what is traditionally called the tragic aorist.” (Bary 2012: 50-51; bold print by me, SH)

If the first-person present is chosen, one prefers present tense over perfective aspect. This choice is clearly encouraged by the inherent time reference of the utterance. If, on the other hand, the first-person aorist is used, the perfective aspect is favored, emphasizing the completeness of the action at the cost of the inherently appropriate present tense.

The form scrīpsī of example (1) does in fact meet all the requirements of a 'performative', of a 'Koinzidenzfall', and even of the 'tragic aorist', since it is a first person (' $I$ hereby write'), it is formally a past tense but arguably refers to a present action ('I hereby write'), and the utterance of the action constitutes the action itself ('I hereby write').

If we were to interpret the Greek state of affairs relative to the $\kappa \alpha \tau \omega \mu \sigma \sigma \alpha$ (6) / ö $\mu \nu v \mu$ (7) situation as inherited from PIE, we could surmise that the dual possibility of expressing a performative (viz. the first-person present indicative and the first-person aorist indicative) continued to be available in the predecessor of Latin, and (after the formal and functional merger of the inherited aorist into the Latin perfect) expect to find both present and perfect forms to be used for the 'Koinzidenzfall'. For the present cf. example (8).

(8) SOS. per Iouem iuro med esse neque me falsum dicere.

MERC. at ego per Mercurium iuro, tibi Iouem non credere. (PLAVT. Amph. 435-436)

'SOS. By Jupiter I swear that I am he, and that I do not say false.

MERC. But by Mercury, I swear that Jupiter does not believe you.'

But for our study, of course only the use of actual perfect forms will be of interest. Note that it does not matter whether the attested form is morphologically a former perfect (pepercī) or a former aorist (parsī). Due to the syncretism of the PIE perfect and aorist in the prehistory of Latin, all the (putative) functions of 
both erstwhile categories would have merged, in principle, in the Latin perfect. Note also that for present purposes it does not matter either, whether this function of the Latin first-person perfect is but a mere replica of the Greek tragic aorist and therefore a Grecism, or if we are dealing with an inherited relic of PIE age. However, we will come back to that below in Section 9.

Where do we expect evidence for potential performatives or instances of the 'Koinzidenzfall' in Latin? The answer is: in every text where a first person uses instantaneous speech. This can be in plays, letters, legal contracts, graffiti, or curse tablets. In what follows, I will present a collection of possible examples taken from exactly these genres. It should be mentioned from the outset, however, that I was not able to find any examples of clear first-person perfect forms in performative usage in a text genre where we would perhaps expect them to show up most consistently, viz. in the plays of Plautus and Terence. ${ }^{5}$ This is obviously a problem for the account presented here since the Greek tragic aorist, the proposed counterpart for the Latin usage in question, is first and foremost found in oral dialogue of tragedies. It is also problematic that no ancient grammarian to my knowledge reports such a usage of the perfect. These two caveats should be kept in mind, but they should not disencourage us from venturing on a novel discussion of the forms in question.

\section{Evidence from the Tabulae Pompeianae Sulpiciorum}

As already mentioned in Section 1, the Tabulae Pompeianae Sulpiciorum (TPSulp.) are wax tablets from a banker's archive and consist of various legal documents. ${ }^{6}$ A large number of those are chirographs - treaties that are handwritten by the initiator who (in most of the cases) acknowledges that he or she owes a sum of money and that "he will return it correctly and in good species" (Sirks 2016: 267). The main and most immediate function of the chirograph is that the writer confirms by his or her own handwriting that he or she has done so-and-so.

The chirographs from the TPSulp. usually consist of two to three wooden tablets coated in wax. The chief actor writes his version of the text on the

5 Two possible examples from Plautus are Merc. 164 and Mil. 1097, but both can be interpreted differently (viz. as 'normal' perfects).

6 Cf. the critical edition Camodeca (1999). 
interior wax faces of two tablets. This interior text often displays unusual spellings, spelling mistakes and progressive phonology. ${ }^{7}$ A second version of the text (the duplicate) is written by a professional scribe on a third tablet (exterior text in 'officialese' Latin), and all three tablets are kept together. See Meyer (2004: 126-134) for pictures and discussion.

The format of the text is consistent and does not only appear as such in the TPSulp. but also in texts from other areas of the empire. ${ }^{8}$

"They invariably begin with a date ..., then give the names of the author-protagonists, who ... claim 'scripsi ...' followed by verbs that make clear which act has been undertaken. 'scripsi me convenisse' denotes a agreement, 'scripsi me accepisse' or 'scripsi me habere' or even 'scripsi me percipere in solutum' a discharge of obligation, 'scripsi me accepisse mutua et debere' ... a loan called a mutuum ...” (Meyer 2004: 149; omitting footnotes)

In Camodeca (1999), we find 43 attestations of scrīpsī (oftentimes written scripssi) in 35 formulaic phrases ( $8 \times$ the duplicate is preserved) in 31 different documents dating from 29 CE onwards. Incidentally, in one case there is a Greek interior version (TPSulp. 78) using the aorist हैyp $\alpha \psi \alpha$.

Of course one could argue that the perfect scripsi here is a variant of the 'Perfekt des Briefstils' - it could be implied that the prospective reader understands the writing down of the chirograph as an accomplished action by the time he or she reads it, just as in 'On day so-and-so I wrote down that I ... '. Rowe (2005), in fact, makes a very interesting observation when he claims that scripsi proves the status of these written contracts as not only probative but also effective, since the use of the (in his view) epistolary past tense scrīpsi makes only sense at the moment of reading aloud.

As a matter of fact, however, one could say that the use of scripsì does not make sense at all; it does not add any information content to the written account. It would not be detrimental to the substance of the contract to replace scripsi me accepisse ... et debere by accepi ... et debeo '[on day so-and-so] I received ... and now I owe ... ' and it would be just as meaningful 'at the moment of reading aloud'. So it seems conceivable that the use of the verb scripsī is intended as a confirmation of the facts and circumstances declared in the contract, as some kind of personal pledge. It is this function that clearly identifies it, in my view, as a performative and makes it comparable to modern-day cases like 'I promise you

7 Cf. Blänsdorf (1996: 87); Sirks (2016: 267).

8 Cf. also Platschek (2013: 134) who discusses a passage in Justinian's Digest that cites the same chirograph formula ille scripsi me accepisse ... and rightly translates 'Ich, der und der, erkläre hiermit schriftlich, erhalten zu haben'. 
that I will pay you back' which amounts to 'I will pay you back' introduced by the performative 'I promise (you that)' serving as a personal confirmation.'

Indeed, there is a cross check to confirm this hypothesis: if scrīpsì were some sort of 'Perfekt des Briefstils', we would expect other first-person verbal forms in the same text to appear exclusively in perfect tense, too. If, however, scrīpsi is a genuine performative, we would, in accordance with the Greek $\kappa \alpha \tau \omega ́ \mu о \sigma \alpha$ (6) / ö $\mu \nu \nu \mu$ (7) situation, expect other performative verb forms of the first person to appear, at least partly, in present tense.

And indeed, in 5 cases (in 3 different texts) the chirographs end with the performative verb fateor '(this,) I hereby declare', in one case (TPSulp. 54) even in a syntagma with a perfect.

(9) fateor autem et iuraui per Iouem et numen diui Aug(usti) me hoc anno pro eodem nulli ali fide mea esse iussisse. (TPSulp. 54.12-14; regularized spelling) 'For I hereby declare and swear by Jupiter and the divine power of the deified Augustus that I have, this year, stood surety on his behalf and on behalf of no one else.'

If scrīpsì (and iūrāuī) were instances of the 'Perfekt des Briefstils' we would expect a consistent usage of perfect forms and, thus, a form fassus sum.

Another piece of evidence that suggests that the 'perfect' forms scrippsi, iūrāui, etc. 'I hereby confirm, swear, etc.' in chirographs constitute an archaism of legal language comes from another first-person perfect indicative that is often used to conclude the chirograph, viz. spopondī 'I hereby solemnly swear' (14× in 13 texts in the TPSulp.).

This performative vow also appears $10 \times$ in 6 texts under the form spepondi, which is an archaism according to Gellius (6.9) and was in use among earlier writers (Valerius Antias, Cicero, Caesar; all first century BCE). In 2 cases, the interior text (the genuine chirograph) has spepondi, while the exterior text (the scribal copy) has spopondi. It seems feasible to assume that the professional scribes knew that the 'correct' form was spopondi and therefore used this form in the exterior version, but that among the vulgus the old form spepondi 'I hereby solemnly swear, ${ }^{\text {,10 }}$ was still wide-spread in the first century CE because

9 Cf. Austin (1975: 69) for this comparison: “(1) primary utterance: 'I shall be there’, (2) explicit performative: 'I promise that I shall be there', and we said that the latter formula made explicit what action it is that is being performed in issuing the utterance: i.e. 'I shall be there'."

10 Adams (1990: 244) claims that spepondi "was presumably an archaic spelling observed by Eunus [i.e. the writer of the chirograph] in earlier documents". According to the numerous orthographical peculiarities that Eunus makes in his writing, however (see Adams 1990: 
of its status as a common oral phrase (in legal context). ${ }^{11}$ If so, chances are considerable that also the use of the perfect itself (as a performative) is an archaism. $^{12}$

\section{Other evidence from Pompeii}

Another possible example of a performative usage of the first-person perfect indicative is found in a graffito from Pompeii (CIL IV 9109), on a wall of a weaving shop.

\section{(10) scripsi coeptum stamini}

decembre VII K(alendas) ianuarias.

'I hereby take note that weaving has begun on December 26.'

The purpose of the graffito is arguably to serve "as a sort of aide-mémoire for keeping track ... of business" (Cooley 2012: 115). The graffito was most probably written on the exact day when the weaving began. Translations such as 'I have written down that the weaving was begun ...' (Cooley l.c.) or 'Ich hab es aufgeschrieben: das Weben angefangen ...' (Hunink 2011: 318) are unpromising: if scripsin referred to an action in the past, this would imply that the writer had written down in a book (or similar) that the weaving had been begun, and that he or she then made the effort to write on the wall the fact that he or she had written down somewhere else that the weaving had been begun, which is, of course, hardly probable.

It is much more likely that the form scrippsi refers to the present act of writing in the sense of 'I hereby take note.' In fact, one could even argue that a performative reading of the verb is the only pragmatically sensible interpretation of the graffito since the omission of it would not change the information content at all, similar to the situation regarding the omission of scrippsi discussed in Section 4.

230-242), it is not very likely that Eunus actually did observe a whole lot of "earlier documents".

11 Compare Modern English I do solemnly swear ... as a common phrase, "with the 17thcentury use of do persisting to the present day” (Jasanoff 2016: 140).

12 Plautus, however, (already?) exclusively uses the present tense with this verb for the 'Koinzidenzfall' as in Capt. 898 ... ERG. sponden tu istud? HEG. spondeo. 'ERG. Do you promise it? HEG: I (hereby) promise.' Cf. also VARRO ling. 6, 69 spondere est dicere spondeo. 


\section{Evidence from letters}

The corpus that the following examples are taken from is Cicero's letters. There, the form scripsī is found ubiquitous and in most of the cases is used as a present perfect 'I have written' as in (11), or a simple past 'I wrote' as in example (12).

(11) de Antonio iam antea tibi scripsi non esse eum a me conuentum. (CIC. Att. 15, 1, 2)

'As for Antonius, I have already written to you that the two of us have not yet met.'

(12) scripsi equidem olim ei iratus, quod ille prior scripserat ... (CIC. Att. 3, 12, 2)

'I did write him once, furious, what he had written to me ...'

Some cases of scrīpsī can indeed be identified as the 'Perfekt des Briefstils' in the sense of 'I write/I am writing/I wrote' as in example (4) above, or in (13).

(13) (letter end) haec scripsi nauigans cum Pompeianum accederem xiiii Kal. (CIC. Att. 16, 7, 8)

'I write this at sea on my way to my Pompeian (villa), August 19.'

Sometimes, however, scrīpsī must indeed be regarded as a 'Koinzidenzfall' 'I hereby write', as in example (14).

(14) (D. Brutus to Cicero) scripsi tibi quae hic gererentur: in itinere est Antonius, ad Lepidum proficiscitur, ... (CIC. fam. 11, 11, 1)

'I hereby write you what is going on here. Antony is on the march, he is going to Lepidus ...'

Since the object of scrīpsī, namely quae hic gererentur, ${ }^{13}$ immediately follows as a written account in the present tense, the use of scripsī as referring to a past event is rather unlikely and the interpretation as a performative suggests itself. However, one cannot conclusively rule out an epistolary use of the perfect for this example.

13 Actually, if scrīpsī were (as it is argued) a non-past tense 'I hereby write', one would expect a quae hic gerantur. The actual attested quae hic gererentur can, however, be 'grammatically' motivated. 
The implicit assumption here is that performatives are not only expressed by verba dicendi but also by verba scribendi. ${ }^{14}$ In fact, the act of writing can indeed be a performative 'speech' act. Korkiakangas (2016: 162-163) calls the verbs of this group, very appropriately in my view, 'writing act' verbs (see also below Section 8). A case in which the performativity of the act of writing is at its full value is the genre of defixiones.

\section{Evidence from defixiones}

Defixiones are curse tablets, usually tiny sheets of lead inscribed with maledictions. Here, the act of writing down the curse arguably constitutes the curse itself. The vital role of performative speech acts and especially the 'Koinzidenzfall' within Latin defixiones has been duly acknowledged and discussed at length by Kropp (2008: 137-160); cf. also Versnel (2010: 348-352); and Urbanová (2014: 1082-1086).

The corpus in consideration here comprises the Tabellae Sulis found in Bath (UK), a collection of about 130 defixiones from the second to fourth centuries CE. See Tomlin (1988). In these, the use of first-person present indicative is well attested. Compare examples (15) to (17).

(15) exẹcro qui inuolauer/it ... (dfx 3.2/78) ${ }^{15}$

'I hereby curse (him) who has stolen ...'

(16) deuoueo eum [q]ui / caracellam meam / inuolauerit . . (dfx 3.2/10)

'I hereby curse him who has stolen my hooded cloak ...'

(17) ... dono ... eum latr[on]/em qui rem ipsa/m involavi[t]... (dfx 3.2/36).

'I hereby hand over the thief who stole this thing ...'

But we also find the use of the first-person perfect indicative of the same verbs in the exact same function, as can be seen from examples (18) and (19).

\footnotetext{
14 In my colloquium presentation, I had also included examples of the 'verbum mittendi' misis in putatively performative usage 'I hereby send' (as in CIC. Att. 3, 8, 4; 3, 9, 3; 12, 18, 2; 14, 13, 6; fam. 8, 8), which I compared typologically to similar phrases in Imperial Aramaic letters containing a performative verb for 'to send' (cf. Gzella 2004: 209; Schwiderski 2013: 165-166). The anonymous reviewers, however, have convinced me that these cases are not necessarily performative and I have consequently left them out of consideration, at least for now. 15 I am following Kropp's citation, for which cf. Kropp (2008).
} 
(18) Mineru(a)e / de(ae) Suli donaui / furem qui / caracallam meam inuo/ lauit ... (dfx 3.2/79)

'To Minerva the goddess Sulis I hereby hand over the thief who has stolen my hooded cloak ...'

(19) Nomine Camulorigis et Titocunae molam quam perdiderunt in fano dei deuoui. (dfx 3.19/3) $)^{16}$

'In the name of Camulorix and Titocuna, I hereby offer the mule (?) that they lost, in the sanctuary of the god.'

The interchange between present forms (ex[s]ecrō, dēuouēo, dōnō) and perfect forms (dēuouī, dōnāuī) for the same function and meaning ('I hereby give, curse, hand over') is exactly what we expect from what was said above in

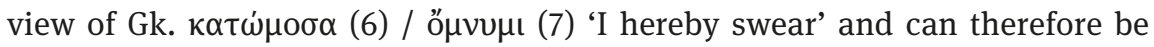
regarded as safe evidence for a performative usage of the first-person perfect in Latin.

\section{Evidence from Oscan and evidence from Late Latin}

Within Ancient Italy, not only Latin seems to have known this usage. In Oscan, the only attested first-person perfect indicative is manafum '(lit.) I handed over, ${ }^{17}$ found twice in one text from Capua (Cp 37 = Ve. 6 in lines 1 and 3), a curse tablet of considerable length.

(20) keri: arent[ikai: man]afum: pai: pụ[i: pu] heriam suvam legi[num: suvam: a]̣luḳad / . . / . . idik: t(i)fei: manafum: . . . (Cp $37=$ Ve. 6.1-3)

'To Ceres Arentica, I hereby entrust, who ... // . . This, I hereby entrust to you ...'

16 This defixio is from Ratcliffe-on-Soar, not from Bath. Note the use of the perfect perdiderunt in the relative clause.

17 The Latin functional and etymological equivalent would be mandāuī; on the formal side, though, -um represents the secondary ending PIE *-om.

18 For a recent discussion of the passage see Dupraz (2012: 220-221) (who translates “I have entrusted”). Álvarez-Pedrosa Núñez (1997: 108) rightfully uses a present tense (“[e]ncomiendo ...") in his translation. 
Murano (2012: 643) rightfully interprets the form manafum as a 'performative aorist' (a term coined by Faraone 1995: 13-14, n. 42), which is, of course, to be equated with the tragic aorist of Section 3. ${ }^{19}$ Since this Oscan text dates from the end of the fourth century BCE, we now have substantial evidence of the performative use of past tense forms of the first-person indicative in two Italic languages over a rather long period of time. In fact, as shown by Korkiakangas (2016: 162-163), the usage of the first-person perfect with 'writing act' verbs is even attested as late as in the Latin of Tuscan Charters of the eighth century CE.

(21) manifestus sum ego Pertifuns quia deuitor sum dare tibi domno Uualprand episcopo soledus propter casa Auderad. (CDL 108; 753 CE)

'I, Pertifuns, make it manifest that I am obliged to give you, Lord Walprand, the bishop, one solidus for the house of Auderad.'

\section{Conclusion}

It remains an open question whether the performative use of the first-person perfect (or, in the Oscan case: aorist) indicative is an inherited function of the PIE aorist, ${ }^{20}$ or if both languages adopted Greek costumes. In Greek defixiones,

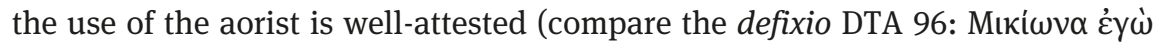

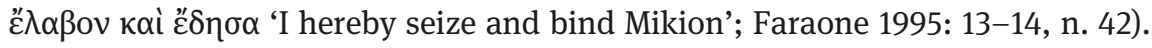
One could, therefore, conclude that using the aorist and the perfect in Oscan and Latin respectively is a mere syntactic Grecism. However, I personally think the examples are too wide-spread in time and space, and from text genres too diverse to be entirely artificial.

Whatever its origin, I hope to have shown that the synchronic usage of the Latin first-person perfect indicative as a performative needs to be acknowledged, and that - even if one disagrees with my interpretation of the facts - this contribution is a step forward in the study of performatives in Latin.

19 Unfortunately, however, she translates the form as 'I have entrusted'.

20 In Vedic, the first-person aorist injunctive is used for the 'Koinzidenzfall' (see Hoffmann 1967: 251-255): .. . J tád u șú prá vocam. (RV 1.164.26) ' ... ] this I hereby proclaim.' ('das verkünde ich hiermit.'; Hoffmann 1967: 251) The aorist injunctive is formally an aorist without the temporal augment (ávocam), which makes sense if we reconsider what has been said in Section 3 (i.e. that the ideal combination for the 'Koinzidenzfall' would be present [or non-past] tense and perfective aspect). The Vedic first-person aorist injunctive can therefore be equated with the Greek tragic aorist, and perhaps also with the Latin perfects scrīpsī, etc., and Oscan manafum. On the performatives Av. stuiiē, Ved. stuṣé 'I hereby praise' cf. Jasanoff (2016). 


\section{Bibliography}

Adams, J. N. (1990). The Latinity of C. Novius Eunus. Zeitschrift für Papyrologie und Epigraphik, 82, 227-247.

Álvarez-Pedrosa Núñez, J. A. (1997). Las defixiones oscas: Composición, interpretación, tipología. Cuadernos de Filología Clásica, Estudios griegos e indoeuropeos, 7, 105-119.

Austin, J. L. (1975). How to do things with words (2ndedition, ed. by J. O. Urmson \& M. Sbisà). Cambridge, MA: Harvard University Press.

Bary, C. (2012). The ancient Greek tragic aorist revisited. Glotta, 88, 31-53.

Blänsdorf, J. (1996). Erborgte und gerettete Schriftlichkeit: Einflüsse der Mündlichkeit in spätantiken Texten. In H. L. C. Tristram (Ed.), (Re)Oralisierung (pp. 85-110). Tübingen: Narr.

Bringmann, K. (1971). Untersuchungen zum späten Cicero (Hypomnemata 29). Göttingen: Vandenhoeck \& Ruprecht.

Calboli, G. (2009). Latin syntax and Greek. In P. Baldi \& P. Cuzzolin (Eds.), New perspectives on historical Latin syntax: Vol. 1, Syntax of the sentence (pp. 65-194). Berlin/Boston: De Gruyter.

Camodeca, G. (1999). Tabulae Pompeianae Sulpiciorum (TPSulp.): Edizione critica dell'archivio puteolano dei Sulpicii. Roma: Quasar.

Cooley, A. E. (2012). The Cambridge manual of Latin epigraphy. Cambridge: Cambridge University Press.

Danckaert, L. (2017). The development of Latin clause structure: A study of the extended verb phrase. Oxford: Oxford University Press.

Dupraz, E. (2012). Sabellian demonstratives, focus and functions. Leiden/Boston: Brill.

Faraone, C. A. (1995). The "Performative Future" in three Hellenistic incantations and Theocritus' second idyll. Classical Philology, 90(1), 1-15.

Gzella, H. (2004). Tempus, Aspekt und Modalität im Reichsaramäischen. Wiesbaden: Harrassowitz.

Haverling, G. (2002). On the semantic functions of the Latin perfect. In A. M. Bolkestein, C. H. M. Kroon, H. Pinkster, H. W. Remmelink \& R. Risselada (Eds.), Theory and description in Latin linguistics: Selected papers from the XIth International Colloquium on Latin linguistics. Amsterdam, June 24 -29,2001 (pp. 153-167). Amsterdam: Gieben.

Hoffmann, K. (1967). Der Injunktiv im Veda: Eine synchronische Funktionsuntersuchung. Heidelberg: Winter.

Hunink, V. (2011). Glücklich ist dieser Ort! 1000 Graffiti aus Pompeji. Lateinisch/Deutsch. Stuttgart: Reclam.

Jasanoff, J. H. (2016). Vedic stușé ‘l praise’. In D. Gunkel, J. T. Katz, B. Vine \& M. Weiss (Eds.), Sahasram Ati Srajas. Indo-Iranian and Indo-European studies in honor of Stephanie W. Jamison (pp. 135-145). Ann Arbor: Beech Stave.

Korkiakangas, T. (2016). Subject case in the Latin of Tuscan charters of the 8th and 9th centuries. Helsinki: Societas Scientiarum Fennica.

Koschmieder, E. (1965). Beiträge zur allgemeinen Syntax. Heidelberg: Winter.

Kropp, A. (2008). Magische Sprachverwendung in vulgärlateinischen Fluchtafeln (defixiones). Tübingen: Narr.

Kühner, R. \& Stegmann, C. (1912). Ausführliche Grammatik der lateinischen Sprache. Zweiter Band: Satzlehre. Hannover: Hahnsche Buchhandlung. 
Lloyd, M. (1999). The tragic Aorist. The Classical Quarterly, 49(1), 24-45.

Meyer, E. A. (2004). Legitimacy and law in the Roman world: Tabulae in Roman belief and practice. Cambridge: Cambridge University Press.

Murano, F. (2012). The Oscan cursing tablets: Binding formulae, cursing typologies and thematic classification. American Journal of Philology, 133, 629-655.

Obcarskas, S. (2017). Foreign merchants in the Sulpicii and Jucundus archives (Unpublished Master's thesis). Universiteit Nijmegen.

Pinkster, H. (2015). The Oxford Latin syntax: Vol. 1, The simple clause. Oxford: Oxford University Press.

Platschek, J. (2013). Das Edikt De pecunia constituta: Die römische Erfüllungszusage und ihre Einbettung in den hellenistischen Kreditverkehr. München: Beck.

Rowe, G. (2005). Roman law in action: The archive of the Sulpicii (TPSulp.), www.law.usc.edu/ centers/clhc/archives/workshops/documents/rowe.pdf (accessed: 10 March 2017).

Schwiderski, D. (2013). Epistolographische Elemente in den neuveröffentlichten aramäischen Ostrakonbriefen aus Elephantine (Sammlung Clermont-Ganneau). In A. F. Botta (Ed.), In the Shadow of Bezalel: Aramaic, Biblical, and Ancient Near Eastern studies in honor of Bezalel Porten (pp. 159-182). Leiden/Boston: Brill.

Sirks, B. (2016). Chirographs: Negotiable instruments? Zeitschrift der Savigny-Stiftung für Rechtsgeschichte: Romanistische Abteilung, 133, 265-285.

Tchernia, A. (2016). The Romans and trade (Translated by J. Grieve, with E. Minchin). Oxford: Oxford University Press.

Tomlin, R. S. P. (1988). The curse tablets. In B. Cunliffe (Ed.), The temple of Sulis Minerva at Bath: Vol. II, Finds from the Sacred Spring (pp. 59-277). Oxford: Oxford University Press.

Urbanová, D. (2014). Die lateinischen tabellae defixionum, der Usus und die Spezifika auf dem Gebiet des Imperium Romanum. In P. Molinelli, P. Cuzzolin \& C. Fedriani (Eds.), Latin vulgaire, latin tardif $X$. Actes du Xe colloque international sur le latin vulgaire et tardif. Bergamo, 5-9 septembre 2012 (pp. 1047-1098). Bergamo: Bergamo University Press.

Verboven, K. (2017). Currency and credit in the bay of Naples in the first century AD. In M. Flohr and A. Wilson (Eds.), The Economy of Pompeii (pp. 363-386). Oxford: Oxford University Press.

Versnel, H. S. (2010). Prayers for justice in East and West: Recent finds. In R. L. Gordon \& F. M. Simón (Eds.), Magical practice in the Latin West (pp. 275-356). Leiden: Brill.

Weiss, M. (2009). Outline of the historical and comparative grammar of Latin. Ann Arbor/ New York: Beech Stave.

Willi, A. (2018). Origins of the Greek verb. Cambridge: Cambridge University Press. 